\title{
IMPLEMENTATION POSSIBILITIES OF A SYSTEM FOR MANAGEMENT AND MEASURING OF SUSTAINABLE DEVELOPMENT OF TOURISM IN METROPOLITAN AREAS: THE CASE OF POZNAŃ AGGLOMERATION
}

\author{
ANNA KRÓLIKOWSKA-TOMCZAK \\ Poznań University of Technology, POLAND \\ e-mail: krolikowska.anna@gmail.com
}

KEYWORDS | sustainable development, tourism management, competitiveness

ABSTRACT Contemporary tourism is facing a lot of challenges. The number of tourists, who are aware and demanding, the quality standards that are being increased, the supplies that are overused in a lot of tourist regions - these are a real problems, that tourist destinations need to face. In such conditions, it is impossible to manage tourism efficiently without any long term strategy, that sets realistic but also ambitious goals, marks out the directions of the development and measures the level of the achievement of the goals in a countable way. As the competition on the tourist market is very demanding, it is important for the destination to fallow present-day trends that promote the idea of sustainability. The theory of sustainable tourism management has been presented in the article, as well as the advantages of its introducing in the process of gaining competitiveness. Most of tourist destinations and agglomerations already has the instruments to do it, they only need to be integrated into a system, that would enable monitoring sustainable tourism development.

\footnotetext{
The biggest challenge that the global tourism sector faces is sustainability.

Tourism continues to grow exponentially - an average of 5 percent a year since 2010 - and by 2030 , we expect international tourists to reach 1.8 billion.

We simply cannot ignore these facts and let the sector grow unmanaged.
}

UNWTO Secretary-General Taleb Rifai

\section{Introduction}

Contemporary tourism is a very complex phenomenon. Depending on the perspective (economical, sociological, psychological) it influences regions, cities, local societies and individuals. The scale of the phenomenon has dynamically increased, exceeding 1 billion of international arrivals in the XXI century, which generated the need of aware, strategic and long term management in tourism field. 
The primary aim of the article is to present the possibilities of managing tourism phenomenon by introducing sustainable tourism indicators system. The particular objectives are indicating connections between tourism and globalization processes and emphasising the need of knowledge based management in this context, as well as pointing out the influence of sustainable management on tourism product and its competitiveness. The practical aspiration was showing existing examples of possible stakeholders group that could support introducing sustainable tourism management system on the example of Poznan agglomeration.

\section{Challenges for tourism in the 21st century in the age of global knowledge-based tourism economy}

The present-day tourism is global. There are many argument to support this. Quantitative structure and growth dynamics of tourism may be the first of them. The number of international arrivals since 2012 has surpassed 1 billion worldwide, and the growth dynamic remains steady, ensuring its further development. Data illustrating the above statements were compiled in Table 1.

Table 1. Number of international travels worldwide in 2000-2014 (in millions) and the growth dynamics of the trend (\%)

\begin{tabular}{lrrrrrrrrr}
\hline \multicolumn{1}{c}{ Region } & 2000 & 2005 & 2010 & 2011 & 2012 & 2013 & 2014 & $\begin{array}{c}\text { Market } \\
\text { share } \\
(\%)\end{array}$ & $\begin{array}{c}\text { Development } \\
\text { dynamics 2012-2015 } \\
\text { (average \%) }\end{array}$ \\
\hline World & 674.0 & 809.0 & 949.0 & 994.0 & $1,039.0$ & $1,078.0$ & $1,133.0$ & 100.0 & 4.3 \\
Europe & 386.6 & 453.2 & 489.4 & 520.6 & 540.9 & 566.1 & 580.1 & 51.2 & 4.0 \\
Asia and Pacific & 110.4 & 154.0 & 205.4 & 218.4 & 233.6 & 249.7 & 264.0 & 23.3 & 5.8 \\
Americas & 128.2 & 133.3 & 150.1 & 155.5 & 162.5 & 167.5 & 181.6 & 16.0 & 5.2 \\
Africa & 26.2 & 34.8 & 49.5 & 49.5 & 51.9 & 54.5 & 55.7 & 4.9 & $0.3^{*}$ \\
Middle East & 22.4 & 33.7 & 54.7 & 49.5 & 50.1 & 48.6 & 51.7 & 4.6 & 5.6 \\
\hline
\end{tabular}

"In 2015 , a decrease in the volume of travel by $6.4 \%$ was observed in the African region compared to 2014 , which can most certainly be associated with the threat to security due to terrorist attacks.

Source: UNWTO (2015).

The United Nations World Tourism Organisation (UNWTO) predicts an increase in the number of international arrivals up to 1.8 billion in 2030 (UNWTO, 2015 Edition). Therefore, from the quantitative point of view, seeing tourism as a global phenomenon cannot be disputed. Qualitative analysis of the phenomenon of tourism leads to similar results: the passive and mass model of tourism described as 3S (Sea, Sun, Sand) led to the development of many new and more niche kinds of tourism (cultural, active, sports, health, and extreme). The number of potential tourist destinations worldwide is difficult to define. More and more countries begin to compete on the tourism market, offering innovative products and climbing in the statistics of number of visits by tourists (United Arab Emirates, Malaysia, Thailand, China). The worldwide tourism emission market is also undergoing revolutionary changes. Just a few years ago, countries separated from the tourism market for political, economic, or other reasons now begin to hold a significant share of this market. According to current statistics of expenditure on tourism, the Chinese are the first, followed by the 
Germans, the Americans, the British, and the Russian citizens (UNWTO Tourism Highlights, 2015 Edition). Globalization of tourism also means its availability from the perspective of an individual tourist: thanks to the development of technology the ability to search and compare tourist offers has become common worldwide. Thanks to low-cost airlines and long-distance ones the world is becoming a "global village", and the importance of spatial distance has decreased significantly.

To sum up reflections regarding the influence of tourism on globalization and vice versa it should be pinpointed that:

- tourism phenomenon and globalization processes are strongly related,

- globalization understood as a technological development raised the availability of tourism mostly because of the Global Distribution Systems Development and transport facilities,

- globalization understood as an internationalization or decreasing importance of traditional meaning of territory led to the appearance new tourist destinations and tourist emission regions,

- the increasing number of tourist may become disadvantage of tourism development in some destinations (cities -f.ex Venice, Barcelona, coastal regions - Andalucia Spain, island countries - Balearic Islands, national parks and reservations etc.).

These mentioned points lead to conclusion that operating on tourism market in the 21 st century enforces strategic and conscious planning, based on gaining competitive advantage through comprehensive knowledge. P. Drucker said that while knowledge may not become the only source of competitive advantage, it will be the most important one (Drucker, 1999). Knowledge-based economy is creation based on using information and knowledge. The more complex the environment in which an enterprise, organization, or destination has to operate, the greater the importance of information and knowledge as well as competence in developing competitive advantage.

In recent years there has been a change in the perception of tourism product and, consequently, a change in regional tourism management. Cities and regions of today are perceived as comprehensive tourism products. A considerable challenge in the strategic approach to their growth is the competition between cities/areas for desirable social opinions and feelings (Glińska, 2011). It expresses the values represented by a given destination and the experience it has to offer (Devashish, 2011). The value may be a key word in this process - especially when the resources are converted into values.

Apart from the global nature of tourism, rational use of resources can be a significant challenge for service providers and organizers active on the tourism market. A resource in tourism can represent diverse components of environment and values. An obvious division is to distinguish natural resources (such as climatic conditions, environmental status, hydrological conditions and resources, terrain layout) and anthropogenic, or cultural resources, such as architectural landmarks and cultural events. Resources can also be divided into tangible and intangible, the latter of which often contribute to shaping competitive advantage in tourism. It can be due to the ambiance of the place, its aforementioned brand, understood as the "sum of emotional advantages" (Mikołajczyk, 2010/20111), or well-displayed local culture and identity. People are also a resource, particularly important in a service-based economy such as tourism economy. The report "Attitudes of Europeans towards Tourism" presents gathered opinions of international tourists in Europe which confirm the 
importance of factors mentioned previously. The respondents named the natural features (climate, landscape, nature, etc.) as the most important factor influencing attractiveness of tourist destination (44\%). It was followed by the quality of accomodation (31\%), then price level and historical and cultural attractions (26\% each), and attitudes towards tourists $(22 \%)$. The latter parameter often seems to be underestimated, whereas in this survey tourists rated it higher than the quality of transport and catering infrastructure or facilities and amenities. Respect towards the above resources and their responsible management may determine the long-term success of a destination. The concept of sustainable development presents an idea of striking a balance between economic values (profit understood as growth), social and environmental ones, and broadly understood order (space). Sustainable tourism management requires profound analysis of the supplies of a given tourist destination in order to define the profile of tourist destination and its development paths. Sustainable tourism management in this case can be called "knowledge based management".

\section{The concept of sustainable management of tourism in a region and the tourism product competitiveness}

Modern conceptions for the growth of tourism, promoted by governmental and non-governmental, global and local organizations, unequivocally indicate that sustainable development, or - regarding the classification of types of tourism - sustainable tourism is the only path of growth for tourism in the 21st century due to its mass nature and the expectations of potential tourists. There are many definitions of sustainable tourism in literature. It is in line with the theory of sustainable growth as such, and its essence seems to be harmonious cooperation and development of tourism on three levels (dimensions) - economic, social, and environmental. Therefore, sustainable tourism is not simply care for the environment but also for long-term economic growth and social justice (Swarbrooke, 1998).

Respect to resources in a sustainable system can be achieved by such growth where meeting the needs now will not limit the capability of meeting the needs of future generations (Weaver, 2007). Sustainable growth means activities based on retaining the long-term ability to use resources, and even the protection of the latter. The development of the phenomenon of tourism to such an extent is advantageous and desirable for a region, as it can significantly affect the competitiveness of the region and the perception of its comprehensive tourism product.

In the traditional approach, the notion of competitiveness was reserved for enterprises or material products, for which objective values such as turnovers, incomes, assets, etc. could be presented. Nowadays, much attention is paid to competitiveness in a broader sense: among other things, the competitiveness of cities and regions from the poing of view of investment potential, quality of life of residents, and attractiveness for tourists as well. It seems relevant that "competitiveness of spatial patterns can be defined as the most effective use of existing resources and innovations in planning and implementation of growth directions" (Kosiedowski, 2002). This theory can be supported with the opinion of Kotler, who believes that the activity which is appropriate from the strategic point of view of entities operating in a market economy is more important than an activity yielding immediate profit (Kotler, 2005). In the above definitions, such terms as "most 


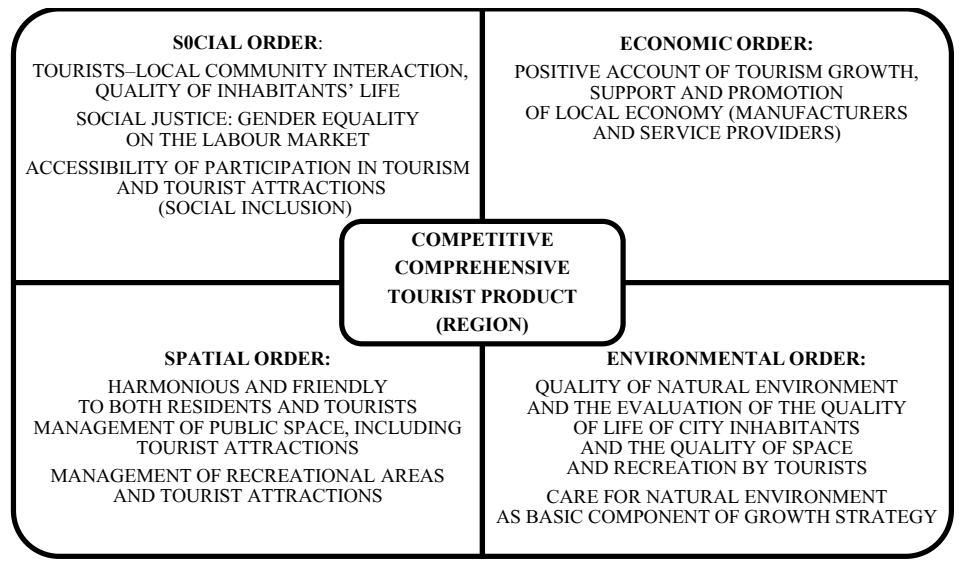

Figure 1. Pillars of sustainable growth and comprehensive perception of tourism product

Source: own research.

effective" or "long-term" seem to announce the theory of sustainable growth, the pillars of which (socio-cultural, economic, and natural environments) are the main planes on which tourism regions compete against one another. It can thus be said that achieving sustainable growth can contribute to an increase in the competitiveness of the tourism reception area, since competitive advantage is built on the relation between resources and conditions which can be taken advantage of in the given area. Thus, preservation of natural and social resources may contribute to increasing the tourism attractiveness of a region (Niezgoda, 2008). In his concept of tourist motivation factors, Professor L. Kozioł distinguishes motivators such as natural an environmental values, hygienic factors - including management of tourism and image of a destination - and demotivators which discourage tourists from a given destination, the chief of which is environmental pollution (Koziol, 2013). This perspective becomes even more important when we analyse the priority of competitiveness of tourism destinations presented, for instance, in the model created by J.R.B. Ritchie and G.I. Crouch, in which competitiveness and sustainable growth are mutually tied with each other. In this model, priority areas are indicated, which contribute to sustainable and competitive growth of tourist destinations. Such areas include destination management, politics, planning and development, as well as multi-aspect micro- and macro-environment (Alejziak, 2009).

\section{Management of competitive development of tourism by monitoring strategic assumptions and pillars of sustainable growth using indicatop methods}

A competitive tourism product on the 21st-century market is an innovative, diverse, and coherent product. It is also a product created with respect to natural and cultural environment, and the functioning local community standards. Sustainable growth of tourism in a region is associated with many issues of growth, even those which significantly affect the quality of life evaluation in both common and statistical context (OECD Indicators). Respect towards natural environment, 
which is one of the aspect of the development of sustainable tourism, is desirable both from the point of view of regional growth and the every-day perception of residents' quality of life. In order to meet the above challenges at the local level, it is necessary to make rational decisions, which are more likely to succeed when they are supported by a thorough analysis based on reliable and objective information gathered through a system of indicators. An efficient tool for sustainable management of moritoring the growth of tourism in a region, suggested by the European Committee, is the European Tourism Indicator System. It was developed and published as part of the realization of the objectives to strengthen the position of Europe (European Union) as the leading tourist destination. Sustainable management of tourism enables assessign the absorbability of a given region, or the level to which tourism can be developed so that the harmony between the visited environment and tourists is preserved, in the environmental, economic, and social context. The aim of sustainable management of tourism is to achieve a broadly understood balance in the growth of tourism, retaining the most beneficial possible relation of profit and loss (inevitable in the case of mass tourism) for the potential region of tourist reception, while enabling the realization of all functions and goals planned by tourists while maximizing their satisfaction.

The concept of the ETIS system concerns the implementation of management of sustainable tourism by gathering and monitoring information based on a system of indicators, and thus diagnosing the problems in the growth of tourism, which may be an independent system or complement the system of tourism monitoring already present in the destination (such as, in Poznań, the Poznań Tourism Barometer; Poznański Barometr Turystyczny). Four groups of indicators can be distinguished in this system, applicable to different areas of human life and functioning of a region: destination management, economic value, effect on society and culture, and impact on the environment. Table 2 presents selected indicators and their meters in the ETIS, along with the evaluation of the usefulness of measuring sustainable growth of urban agglomerations.

Table 2. Chosen indicators of ETIS and the evaluation of their usefulness for measuring sustainable growth in urban agglomerations

\section{Section I: Destination Management}

\section{Criteria and example of indicators:}

1. Sustainable Tourism Public Policy

- Percentage of the destination with sustainable strategy

2. Customer Satisfaction

- Percentage of visitors satisfied with their overall experience

- Percentage of return visitors (within 5 years)

3. Information and Communication

- The percentage of visitors who note that they are aware of destination sustainability effort

\footnotetext{
Evaluation of the usefulness of a group of indicators for measuring sustainable growth in an urban agglomeration:

The presented indicators give a general idea of the awareness of the need to implement sustainable growth strategies in tourism in a given destination and show the tourists' level of satisfaction. It is of significant value for the planning of strategic development of tourism on a complex, global market, where the quantitative approach seems to be replaced by the qualitative one. Currently, many destinations face the issue of decreased quality of tourism product due to overcrowding (Barcelona, Venice). Many destinations focus on the quantitative characteristic and defining the demographic and economic profile of tourists and their consumption model, marginalizing the issue of evaluating their satisfaction. Taking into account the fact that the European Tourism Indicator System can be flexibly developed, using the given indicators as main guidelines, their structure can be freely developed depending on the nature of the destination. It seems important to investigate the perception of activities for sustainable growth in order to possibly intensify them or make them more visible.
} 


\section{Section II: Economic Value}

Criteria and example of indicators:

1. Tourism Flow

- Number of tourist nights per night

- Number of same day visitors

- Daily spending per same day visitor and tourist

2. Tourism Enterprise(s) Performance

- Average length of stay

- Occupancy rate in commercial accommodation per month and average for year

3. Quantity and Quality of Employee

- Direct tourism employment as \% of total employment

4. Tourism Supply Chain

- Percentage of tourism enterprises taking steps to source local, sustainable and fair trade goods

- Percentage of tourism enterprises sourcing $25 \%$ of local products

The demonstration of the role of tourism in the economic growth of a region, is the most important argument for the growth of tourism. The presented indicators objectively present the current situation and may suggest further paths for growth. They also draw attention to the frequently underestimated values on the tourism market, such as local delivery chains. The development of intra-regional cooperation to provide services for tourists and one-day visitors through the development of a local delivery chain may directly contribute to the growth of local economy.

The level of employment in the tourism sector depends on the developmental level of this phenomenon in the region. It may also be an argument for supporting the development of tourism at the strategic planning level, especially in the context of preventing unemployment among young people, who are the largest percentage of workforce in the tourism services sector. The qualitative and quantitative structure of the tourists' stay at the destination, which can be described using the indicators measuring tourist flow is also highly valuable information, which may contribute to accurate profiling of a tourist product and addressing it to a desired target sector.

\section{Section III: Social and Cultural Impact}

Criteria and example of indicators:

1. Community/social impact

- Number of tourists per 100 residents

- Percentage of residents who are satisfied with tourism in the destination

2. Gender Equality

- Percentage of tourism enterprises where the general manager is held by woman

3. Equality/Accesibility

- Percentage of commercial accommodation and tourist attractions accessible to people with disabilities

4. Protecting and Enhancing Cultural Heritage, Local Identity and Assets

- Percentage of residents who have positive (or negative) views on the impact of tourism on destination identity

\section{Evaluation of the usefulness of a group of indicators for measuring sustainable growth in an urban agglomeration:}

Parallel to the process of regional integration in the European Union, there are activities to promote and advertise local identities, present individuality and various values, which make individual regions unique. In the global age, it seems advisable to expose the local values and, in consequence, strengthen the local cultural identity. Equal rights and equalization of opportunities can take various forms (gender, disability, age). The social policy of the European Union promotes activities leading to the inclusion of all groups to function in the society on equal rights. In Poland, there is still very much left to do in this matter. It is therefore even more significant to monitor the situation regarding accessibility of tourism services for persons with disabilities and other limitations in the region which aspires to develop its tourism function.

The indicator concerning the number of tourists in comparison to the number of residents, along with the indicators of tourist capacity and absorbability may deliver invaluable information regarding the intensification of tourist flow in individual periods of time, manage the structure of the tourist flow, and diagnose possible problems, e.g., associated with overcrowding in the peak season. Sustainable growth is, simply speaking, a harmonious growth combining interests of all groups without conflict, contributing to the improvement in quality of life and not threatening this value. The resultant of indicators from this group is a good source of information for planning the strategic product growth.

\section{Section IV: Environmental Impact}

\section{Criteria and example of indicators:}

1. Reducing Transport Impact

- Percentage of tourists and same day visitors using different modes of transport

- Percentage using local transport

2. Solid Waste Management

- Volume of waste recycled 


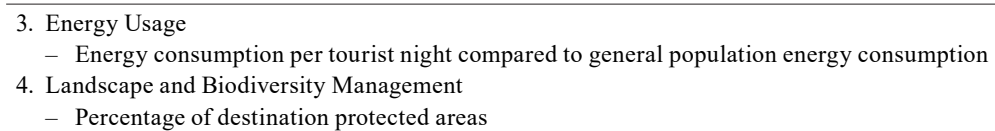

Percentage of destination protected areas

\section{Evaluation of the usefulness of a group of indicators for measuring sustainable growth in an urban agglomeration:}

At present, the care of natural environment seems not just an obvious value but also an obligation. It is one of the key components of sustainable growth. In the context of the growth of tourism, the care for natural environment is doubly important since the relation between tourism and nature is a feedback loop. Natural assets, natural environment, clean, not polluted nature, air - these are all values sought after by tourists, showing the quality and attractiveness of a tourist attraction. Thus, tourism benefits from sustainable growth in the context of ecological values. However, its mass and uncontrolled growth may greatly upset this balance. The importance of monitoring the status of the environment of a tourist destination and the effect of tourism growth on this status seems obvious and impossible to overestimate now.

Source: autor's own work based on European Tourism Indicators... (2013).

ETIS is a flexible tool which seems to analyse the most significant areas of functioning of tourism destinations. It is also the newest system of indicators for measuring sustainable growth, but obviously not the only one. For example, it is worth mentioning here the earlier project, of Scandinavian origin, the Network Evolution for Sustainable Tourism (NEST), comprised of 21 indicators; the indicator system suggested by the United Nations World Tourism Organizetion (UNWTO); sustained growth indicators advocated by the World Tourism and Travel Council (WTTC), or a similar system of indicators by OECD - the Measuring Competitiveness in Tourism. There are also many sets of indicators of sustainable growth in a general sense, not dedicated for any specific industry but rather comprehensive measurement of sustainable growth on the scale from local to nation-wide. It is enough to name here the sustainable growth indicators of the World Bank, OECD or, on the national scale the Indicators of Sustainable Growth of Poland (GUS).

\section{Implementation possibilitites for a sustainable growth management system in the Poznań agylomeration}

The strength of ETIS is its form of a manual, in which the decision-makers in charge of a destination may find suggestions on the implementation procedure for sustainable management of tourism. Among other things, ETIS includes a suggestion of an executive group composition, which is on the one hand flexible and permits adaptation to the conditions of the region, while on the other provides a comprehensive membership and covers all the areas of competence monitored by ETIS. What seems of particular importance is the interdisciplinary character of the stakeholders' group. Apart from various competences (culture, nature, management), there is an added value in the form of a varied organizational character and belonging to either the private or public sector, performing both commercial and scientific activities. The Poznań Tourism Organization (Poznańska Organizacja Turystyczna), operating in the Poznań metropolitan area, is an association of local governments (the City of Poznań and 23 local governments of neighbouring municipalities), local government organizational units (Municipal Transport Company in Poznań), hotels and travel agents, restaurants and cultural institutions, as well as universities and enterprises. The above structure enables gathering interdisciplinary data and, in relation to ETIS, to monitor the majority of indicators of sustainable growth of tourism. Moreover, supplementing its structures with 
members of the Poznań Metropoly (Metropolia Poznań) association could allow to increase the study area in both territorial and substantive terms (8 additional local government units).

Table 3 presents the compilation of structures in the case of the Poznań aTourism Organization and Poznan metropolitan association.

Table 3. Example of the structure of units involved in the system of sustainable structural management taking into account the Poznań Tourism Organization and Poznań Metropoly Association

\begin{tabular}{ccc}
\hline Structure suggested in ETIS (stakeholders) & $\begin{array}{c}\text { Members of PLOT (Poznań Local } \\
\text { Tourism Organization) }\end{array}$ & $\begin{array}{c}\text { Members of the Metropolitan Poznań } \\
\text { Association }\end{array}$ \\
\hline
\end{tabular}

Private sector representative - e.g. head $\quad$ Private sector PLOT members' Representatives of hoteliers and travel

of local hotel associacion representative agents operating in the metropolitan area

Destination Management Organization $\quad$ Executive Board of PLOT PLOT, Department of Tourism and Sport of the Marshal's Office, Tourist Organization of Greater Poland, local government units of the associated areas whose competences include the tasks related to tourism policy

\begin{tabular}{|c|c|c|}
\hline Tourism Authority & $\begin{array}{l}\text { Polish Chamber of Toruism - Greater } \\
\text { Poland Chapter in Poznań, Greater } \\
\text { Poland Chapter of Gastronomy }\end{array}$ & $\begin{array}{l}\text { Polish Chamber of Toruism - Greater } \\
\text { Poland Chapter in Poznań, Greater Poland } \\
\text { Chapter of Gastronomy }\end{array}$ \\
\hline Educational institution & $\begin{array}{l}\text { University of Economy, Department } \\
\text { of Tourism (PLOT member) }\end{array}$ & $\begin{array}{l}\text { University of Economy, Department } \\
\text { of Tourism } \\
\text { Poznań University of Technology, Faculty } \\
\text { of Engineering Mangement, Department } \\
\text { of Entrepreneurship and Business } \\
\text { Communication, } \\
\text { University School of Physical Education } \\
\text { in Poznań, Faculty of Tourism }\end{array}$ \\
\hline $\begin{array}{l}\text { Organization concerned with preservation of } \\
\text { culture \& heritage }\end{array}$ & $\begin{array}{l}\text { Marshal's Office - Department } \\
\text { of Culture } \\
\text { Voivodeship Office for Protection } \\
\text { of Monuments } \\
\text { Cultural institutions associated in } \\
\text { PLOT: Brama Poznania ICHOT } \\
\text { (Gate of Poznań: Interactive Centre } \\
\text { of the History of Ostrów Tumski), } \\
\text { Cultural Centre "Zamek" }\end{array}$ & $\begin{array}{l}\text { Marshal's Office - Department of Culture } \\
\text { Voivodeship Office for Protection of } \\
\text { Monuments } \\
\text { Local government units responsible for the } \\
\text { management of culture, } \\
\text { Cultural institutions operating in the met- } \\
\text { ropolitan area, not associated in PLOT }\end{array}$ \\
\hline Local government transport department & $\begin{array}{l}\text { Marshal's Office - Department } \\
\text { of Transport, Municipal Transport } \\
\text { Company; additionally - Ławica Airport }\end{array}$ & \multirow{4}{*}{$\begin{array}{l}\text { Local government units with competences } \\
\text { in selected issues: according to the territory } \\
\text { of the Poznan metropolitan area, to supp- } \\
\text { mement the members of PLOT. }\end{array}$} \\
\hline Local government Climate Department & $\begin{array}{l}\text { Marshal's Office - Department } \\
\text { of Environment }\end{array}$ & \\
\hline Local government water and sewage provider & Aquanet sp z o.o & \\
\hline $\begin{array}{l}\text { Organization concerned with protection } \\
\text { of the local environment }\end{array}$ & $\begin{array}{l}\text { Marshal's Office - Department } \\
\text { of Environment }\end{array}$ & \\
\hline
\end{tabular}

Source: own research.

\section{Conclusions}

In the age of global economy, the competitiveness of a tourist reception area depends on a number of factors: natural and cultural values, ambiance of the place, quality and innovativeness of the tourism product. The theory of sustainable growth of the region, in strict terms, and 
of sustainable growth of tourism in a given area set ambitious goals in the form of rational use of resources and striking a balance between economic value and socio-cultural and natural environment. ETIS, the system presented in this paper is one of many possible solutions; howevere, it is an ordered structure with a broad spectrum of indicators, which enable the observation and diagnosis of growth of tourism in a region in its various spheres of influence. Moreover, supplementing this system with already existing (like the Tourism Barometer in the case of Poznań) or new indicators (of competitiveness or innovativeness) may result in a comprehensive diagnostic and prognostic tool. The Poznań agglomeration, similar to other Polish cities, seems to already have ready-made tools at the level of institutions, which only require an integrative approach. The activity of Local Tourism Organizations, associating members from various disciplines, provides a basis for the implementation of comprehensive tools for the management of tourism in the region.

\section{References}

Alejziak, W. (2009). Współeczesne modele i wybrane koncepcje polityki turystycznej. Gospodarka Turystyczna w Regionie. Przedsięborstwo. Samorząd. Wspótpraca, 50.

Attitudes of Europaens towards tourism. Brussels: TNS Political and Social (requested by European Commission).

Devashish, D. (2011). Tourism Marketing. New Dheli: Pearson.

Drucker, P. (1999). Społeczeństwo prokapitalistyczne. Warszawa: Wydawnictwo Naukowe PWN.

Echtner, C., Ritchie, J. (1993). The Measurement of Destination Image - An Empirical Assessment. Jurnal of Tracel Research, 1 .

European Tourism Indicators System for Sustainable Destinations (2013). Bruksela: European Commission.

Glińska, E. (2011). Sposoby badania wizerunku miasta. Samorząd Terytorialny, 11, 33-44.

J., S. (1998). Sustainable Tourism Managment. Cabi Publishing.

Kosiedowski, W. (2002). Przedsiebiorczość i innowacyjność jako czynniki rozwoju regionalnego i lokalnego. Włocławek: Włocławskie Towarzystwo Naukowe.

Kotler, P. (2005). Marketing. Poznań: Dom wydawniczy Rebis.

Kozioł, L. (2013). Koncepcja klasyfikacji czynników motywacji turystycznej. Współczesne Zarządzanie, 1.

Mikołajczyk, A. (2010/2011). Budowa marki miasta. Thinktank, 7, 1-7.

Metropolia Poznań 2020 (2011). Strategia Rozwoju Aglomeracji Poznańskiej. Poznań: CBM. Available at: http://metropolia2020.poznan.pl/tresc-dokumentu.

Niezgoda, A. (2008). Cele zrównoważonego rozwoju a przewaga konkurencyjna obszaru recepcji turystycznej (pp. 19-31). In: G. Gołembski (ed.), Turystyka jako czynnik wzrostu konkurencyjnosci regionów w dobie globalizacji. Poznań: Wydawnictwo Akademii Ekonomicznej w Poznaniu.

UNWTO (2015). Tourism Highlights. Madrid: UNWTO.

Weaver, D. (2007). Sustainable tourism. Routledge.

Zdon-Korzeniowska, M. (2009). Jak kształtować regionalne produkty turystyczne? Teoria i praktyka. Kraków: Wydawnictwo Uniwersytetu Jagielońskeigo. 


\section{MOŻLIWOŚCI WDRAŻANIA SYSTEMU ZARZĄDZANIA ZRÓWNOWAŻONYM ROZWOJEM TURYSTYKI W REGIONACH METROPOLITARNYCH NA PRZYKŁADZIE AGLOMERACJI POZNAŃSKIEJ}

SŁOWA KLUCZOWE

STRESZCZENIE zrównoważony rozwój, zarządzanie rozwojem turystyki, konkurencyjność destynacji turystycznej

Współczesna turystyka staje przed wieloma wyzwaniami. Wzrastająca liczba coraz bardziej świadomych i wymagających turystów, coraz wyższe standardy jakości oraz nadużywanie nieodnawialnych zasobów w wielu regionach turystycznych - to problemy, którym muszą stawić czoła destynacje turystyczne. W powyższych warunkach, niemożliwym jest efektywne zarządzanie turystyką bez strategii o perspektywie wieloletniej, w której definiowane są realne ale ambitne cele, wyznaczane kierunki rozwoju oraz wskazywane narzędzia służące pomiarowi i analizie osiągnięcia założeń. Konkurencja na rynku turystycznym jest bardzo wymagająca, dlatego też w zarządzaniu destynacją turystyczną szczególnie istotną rolę odgrywa obserwacja współcześnie panujących na rynku trendów, spośród których szczególnie istotnym wydaje się być promowanie idei zrównoważonego rozwoju.

W artykule przedstawiono teorię zrównoważonego rozwoju w zarządzaniu regionem turystycznym oraz mocne strony niniejszego podejścia w kontekście budowania przewagi konkurencyjnej. Głównym celem artykułu jest wskazanie możliwości zarządzania zrównoważonym rozwojem turystyki przez wdrożenie systemu wskaźników zrównoważonego rozwoju. Jako cele szczegółowe wskazać należy przedstawienie zależności pomiędzy procesami globalizacji a rozwojem turystyki (i vice versa), podkreślenie potrzeby i istoty zarządzania opartego na wiedzy i informacji oraz podkreślenie wpływu zrównoważonego zarządzania na konkurencyjność destynacji. 